\title{
Introduction to Research Handbook on the Sociology of Law \\ Jiři Přibán̆
}

Handbooks have become increasingly popular among academics and their publishers in the last two decades. They are an intellectual response to the growing complexity and sheer amount of research conducted in all areas of science, including sociology of law and socio-legal studies. They also are an effect of digitalisation of scientific communication, online accessibility and new ways of research dissemination. While monographs and edited books related to the specific research areas often struggle to draw attention, generalising and synthesising volumes bringing together different disciplines, theories and perspectives offer an overview and intellectual orientation in relevant areas of academic research.

Handbooks on the most diverse themes and problems, from global constitutionalism and philosophies of law to the legal regulation of railway transport and virtual reality, have been published in recent years. Their popularity is particularly strong in interdisciplinary and transdisciplinary research of law. A researcher interested in 'law and society' or 'law in context' studies, therefore, can already use a number of collections, such as: the three volume Encyclopedia of Law \& Society, edited by David S. Clark (2007); the extensive Law and Society 'mini-library' in four volumes, edited by Dave Cowan, Linda Mulcahy and Sally Wheeler (2014); The Handbook of Law and Society, edited by Austin Sarat and Patricia Ewick (2015); the Journal of Law and Society's special supplement Main Currents in Contemporary Sociology of Law, edited by Jiří Přribáň (2017a); and, most recently, the Routledge Handbook of Socio-Legal Theory and Methods (Creutzfeldt, Mason and McConnachie 2020).

Furthermore, handbooks on law and gender (Ashford and Maine 2020), race and class (Jackson 2015), science and technology (Brownsword, Scotford and Yeung 2016), medicine and health (Jacob and Kirkland 2020), crime and criminal justice (Tonry 2011) and other areas of national and transnational law (Halliday and Shaffer 2015) provide for the most detailed mapping of studies of law in social context. Numerous edited volumes on law and other social phenomena, and problems and themes, are being published in book series specialising in law and society studies by many academic publishers every year.

Editing a specific handbook on sociology of law in this very rich, diverse, competitive and successful academic environment is a difficult task. It would make no sense to replicate important topics and problems of sociological research of law and socio-legal studies which already have been covered well by other handbooks, such as race, gender, class, and social or criminal justice and injustices. It would also be useless to focus on widely addressed transformations of contemporary positive law, such as the emergence of transnational legal systems and globalization of law and society.

Indeed, no sociologist of law can ignore these topics and developments of subnational, transnational and global legal orders, and systems operating beyond the state. Individual 


\section{Research handbook on the sociology of law}

chapters in this Handbook document this shift in sociology of law and socio-legal research very well. However, they have become an integral part of any socio-legal research and, therefore, do not need to be addressed as specific problems, yet again.

A research handbook on sociology of law, rather, needs to connect the discipline's origins and genealogy with its current state and future ambitions. While avoiding artificial academic borders and distinctions between sociology of law, socio-legal, or law and society studies, it should outline both the sociology of law's uniqueness and commonalities with other social and legal sciences. Finally, it should discuss its canonical knowledge and concepts as much as possible, and ways of moving beyond them.

Indeed, the long tradition of sociology of law consists of many different theoretical schools, methodologies and intellectual perspectives also associated with 'sociological jurisprudence', 'law and society', 'socio-legal studies' and other academic labels. Differences between common law and civil law cultures play their role in different perceptions of sociology of law, its theoretical autonomy, and its impact on legal policies. While the common law legacy of Roscoe Pound's sociological jurisprudence as a policy-oriented and critical analysis of positive law still finds its echoes in contemporary 'law and society' and 'socio-legal studies' approaches, sociologists of law in civil law cultures tend to emphasise the importance of doctrinal knowledge and, like Eugen Ehrlich and Georges Gurvitch a century ago, often continue to ambitiously perceive their academic discipline as the most general science and theory of positive law (Treviño 2008).

These theoretical, conceptual and methodological differences surprisingly persist in contemporary sociological explorations of law in its local, national and transnational globalised contexts (Twining 2000; Hertogh 2009). Furthermore, the classic distinctions between living and legislated law or law in books and law in action are translated into jurisprudential notions of legal monism and pluralism (Přibáň 2017b, 3-5); societal processes of evolution, fragmentation and hybridization have become leading concepts of theories of legal globalization (Teubner 2012). In other words, the conceptual framework and distinctions established by the first generation of sociologists of law a century ago has become an intrinsic part of general theories and jurisprudence of contemporary law. Today, sociology of law prevails as both a general theory of law and a specific set of empirical methods and practical tools that examine societal operations of different legal systems, orders and regimes.

This Handbook on sociology of law, therefore, aims at mapping the discipline in its histori$\mathrm{cal}$, theoretical and methodological contexts, and as a complex social scientific research of positive law. It is composed as a set of inquiries into the current state of sociology of law as a unique academic discipline which, nevertheless, flourishes due to its strong capacity of interdisciplinary engagement and links to other scientific concepts, methodologies and research fields.

Reflecting on recent publications in sociology of law, law and society, socio-legal studies and interdisciplinary research of law, this Handbook revisits the specific role of sociology of law, its disciplinary boundaries and its relationship to both legal and social sciences. Individual chapters in the first part focus on the sociology of law's relationship with other academic disciplines, such as legal theory and jurisprudence, anthropology, ethnography, history, economics, or science. Joxerramon Bengoetxea explores close links between legal theory and sociology of law and different uses of sociological theories and knowledge 
by legal theorists. Roger Cotterrell revisits the concept of sociological jurisprudence and transforms its traditions into a new theoretical enterprise, reformulating the position of sociology of law and its relationship to both legal and social sciences. Chloë Kennedy then analyses another strong link, namely between the sociology of law and legal history and their respective methodologies. Similarly, Fernanda Pirie describes commonalities and similarities between sociology of law and legal anthropology. Close to anthropology, ethnographic studies of law have a long tradition and Anne Griffiths rethinks it in the context of sociological, even philosophical, conceptualisations of power, discourse and knowledge. The first part of the Handbook subsequently continues with sociological inquiries into the relationship between law, power and hegemony constituted by other social systems. While Iagê Miola and Sol Picciotto deal with power and inequalities constituted by the economic system, Emilie Cloatre and Martyn Pickersgill explore different forms of communication and interaction between law and science. The opening part then ends with Bettina Lange's analysis of regulation studies and the role of sociology of law in this field of interdisciplinary research.

In the second part, the Handbook revisits key sociological inquiries into positive law concepts, such as the rule of law, living law, legal systems, legal culture, legal consciousness, subjectivity, temporality, legal images and professions. This framework demonstrates the indispensability of sociology of law and its methodology in legal science as much as the impossibility to reduce it to the set of empirical methods supporting either legal policies and jurisprudence, or their criticisms. Individual chapters create a complex fabric of both the general and specific sociological meaning of positive law, its structure, organisation and function. Jiří Přibán̆ taps into the rule of law traditionally dominated by legal and political theorists and philosophers to highlight sociological origins and contexts of legality and legitimacy. Marc Hertogh explores the legacy of Ehrlich's concept of living law as 'the other hemisphere of the legal world'. David Nelken revisits the concept of legal culture and its importance for sociological research of law. Richard Nobles and David Schiff use the social systems theoretical perspective to examine and reformulate the concept of legal system. Patricia Ewick and Susan Silbey examine the relationship between legal consciousness and hegemony, and thus link general issues outlined in the first part of the Handbook to the more specific problems of power and hegemony evolving in the system of positive law. Pierre Guibentif then formulates a powerful sociological theory of legal subjectivity, and Lyana Francot engages with the systemic conceptualisations of time in law and society. Drawing on the semantics of law, Linda Mulcahy's chapter is closely connected to Guibentif and Francot's analysis of the legal constitution of subjectivity and temporality because it offers a sociological analysis of the constitution of different legal images. The second part of the Handbook is then completed by another internal construct of the legal system, namely legal professions examined by Lisa Webley.

Following these sociological explorations of the concept of law and legal system, the final part of the Handbook engages with sociological perspectives applicable to the specific legal disciplines and different areas of positive law. Contributors do not focus on particular jurisdictions and legal cultures and their comparisons. Instead, they outline general concepts, themes, problems and trends in their social and legal contexts. This part opens with two chapters dealing with the sociology of constitutional law. While Paul Blokker offers a detailed sociological assessment between the systems of law and politics, including the differences between legal and political science, Chris Thornhill 


\section{Research handbook on the sociology of law}

presents a rapidly expanding field of sociology of transnational constitutions and global constitutionalism.

In the following two chapters, Sarah E. Hamill offers an outline of sociological conceptualisations of contract and property law, and deals with current methodological problems as much as future challenges for this particular field of sociology of law, while Antonia Layard examines the concept of property in its socio-legal context and combines it with the perspective of post-colonial studies. These explorations of contract and property are followed by three chapters that focus on the closely connected institutions of family and religion and the integrity of human life. While Mavis Maclean reflects on the specific evolution of international collaborative networks of sociologists of family law, Russell Sandberg examines the historical and intellectual development of law and religion studies and its sociological dimension. Atina Krajewska's contribution is closely related to these chapters because it explores theoretical and ethical issues of another extremely dynamic and fast developing field, namely health law and its globalization.

The following three chapters engage with problems of social justice and injustices in the realm of criminal law, housing law and labour law. Sharyn Roach Anleu revisits the classic concepts of deviance and crime and comments on its theoretical, sociological and social injustice dimensions, including gender discrimination and the process of deviantisation. Dave Cowan and Sally Wheeler look at the history and sociology of housing law and interdisciplinarity of this area of research. Ralf Rogowski then contributes by sociologically assessing a branch of law historically evolving by societal and political regulation of contractual freedom, namely labour law, its institutional developments and globalisation.

The final two chapters of this volume deal with the most general and acute issues of legal regulation, namely artificial intelligence and transitional justice. These two areas of research may look very different, yet they illuminate the global dimension of contemporary law as much as the need to respond to its challenges, injustices and contingencies by innovative forms of sociological and interdisciplinary research. Håkan Hyden presents a sophisticated analysis of artificial intelligence and digitalisation, and possible legal responses to these societal developments. Similarly, Stephan Parmentier and Camilo Eduardo Umaña Hernández address the 'eternal' problem of political crimes and injustices, yet their response also searches for innovative sociological explanations and clarifications in the context of our globalised social and political experiences.

The reader can see that the contributors to this Handbook represent a collective of scholars fairly balanced in terms of gender, age and academic position, bringing together young talents as well as leading scholars in sociology of law. Although the majority of the contributors are based at universities in the United Kingdom, there are scholars from other countries and continents participating in this project who illuminate the current state, rich history, intellectual traditions and innovative responses to the future challenges of sociology of law.

As a scholar of law graduating from Charles University in Prague, and having research experiences in Africa, the Americas and Central and Eastern Europe, I wanted to see more colleagues from those and other places contributing to this volume, but my efforts did not fully materialise for various reasons. However, this particular failure will hopefully be turned into future successes and more handbooks on sociology of law demonstrating the growing global body of knowledge and community of scholars working in this particular 
academic discipline. In other words, the history and story of sociology of law is to be continued ...

Finally, I want to thank the Czech artist Tomáš Císařovský for giving permission to use his painting Justice on the Handbook cover. It dates back to 1992 when the 1989 revolutionary illusions started disappearing and people realised how fragile and even obscured, yet indispensable the ideal and image of justice could be in modern complex society.

\section{REFERENCES}

Ashford, Chris and Alexander Maine (eds). 2020. Research Handbook on Gender, Sexuality and the Law. Cheltenham: Edward Elgar Publishing.

Brownsword, Roger, Eloise Scotford and Karen Yeung (eds). 2016. The Oxford Handbook of Law, Regulation and Technology. Oxford: Oxford University Press.

Clark, David S. (ed). 2007. Encyclopedia of Law and Society: American and Global Perspectives. 3 vols. Thousand Oaks, CA: Sage.

Cowan, Dave, Mulcahy, Linda and Sally Wheeler (eds). 2014. Law and Society. 4 vols. Oxford: Routledge.

Creutzfeldt, Naomi, Marc Mason and Kirsten McConnachie (eds). 2020. Routledge Handbook of Socio-Legal Theory and Methods. Oxford: Routledge.

Halliday, Terence C. and Gregory Shaffer (eds). 2015. Transnational Legal Orders. Cambridge: Cambridge University Press.

Hertogh, Marc. 2009. Living Law: Reconsidering Eugen Ehrlich. Oxford: Hart Publishing.

Jackson, Shirley A. (ed). 2015. Routledge International Handbook of Race, Class, and Gender. Oxford: Routledge.

Jacob, Marie-Andrée and Anna Kirkland (eds). 2020. Research Handbook on Socio-Legal Studies of Medicine and Health. Cheltenham: Edward Elgar Publishing.

Přibáň, Jiří (ed). 2017a. Main Currents in the Contemporary Sociology of Law. Special Supplement of the Journal of Law and Society 44(S1).

Přibáň, Jiří. 2017b. "A Sociology of Legal Distinctions: Introducing Contemporary Interpretations of Classic Socio-legal Concepts". In Jiř́i Prribán̆ (ed). Main Currents in the Contemporary Sociology of Law. Special Supplement of the Journal of Law and Society 44(S1), 1-18.

Sarat, Austin and Patricia Ewick (eds). 2015. The Handbook of Law and Society. Oxford: Wiley.

Teubner, Gunther. 2012. Constitutional Fragments: Societal Constitutionalism and Globalization. Oxford: Oxford University Press.

Tonry, Michael (ed). 2011. The Oxford Handbook of Crime and Criminal Justice. Oxford: Oxford University Press.

Treviño, Javier A. 2008. The Sociology of Law: Classic and Contemporary Perspectives. New York: Routledge.

Twining, William. 2000. Globalisation and Legal Theory. Cambridge: Cambridge University Press. 